\title{
Pengujian Pupuk Hayati Agrobost dan Pemangkasan Terhadap Pertumbuhan dan Hasil Tanaman Tomat (Lycopersicum esculentum Mill.)
}

\author{
( Study of Agrobost Biofertilizer and Pruning On Growth and yield of Tomato \\ (Lycopersicum esculentum Mill.) Plants )
}

\author{
Mainannur ${ }^{1}$, Rita Hayati ${ }^{1}$, Nurhayati ${ }^{{ }^{*}}$ \\ ${ }^{1}$ Program Studi Peternakan, Fakultas Pertanian, Universitas Syiah Kuala
}

\begin{abstract}
Abstrak. Penelitian ini bertujuan untuk mengetahui pengaruh konsentrasi Pupuk hayati Agrobost dan pemangkasan pada tanaman tomat yang tepat serta mengetahui interaksi antara konsentrasi pupuk hayati Agrobost dan pemangkasan terhadap pertumbuhan dan hasil tanaman tomat. Penelitian ini dilaksanakan di kebun percobaan sektor Timur, Fakultas Pertanian, Universitas Syiah Kuala, yang telah berlangsung dari bulan November sampai dengan Februari 2018. Rancangan yang digunakan adalah Rancangan Acak Kelompok (RAK) pola faktorial $5 \times 3$ dengan tiga ulangan. Faktor yang diteliti yaitu konsentrasi pupuk hayati Agrobost (K) yang terdiriatas 5 taraf yaitu Ko $=$ Kontrol (tanpa pupuk hayati Agrobost), $\mathrm{K}_{1}=5 \mathrm{cc} / \mathrm{L}$ air, $\mathrm{K}_{2}=10 \mathrm{cc} / \mathrm{L}$ air, $\mathrm{K}_{3}=15$ $\mathrm{cc} / \mathrm{L}$ air, $\mathrm{K}_{4}=20 \mathrm{cc} / \mathrm{L}$ air. Faktor kedua yaitu pemangkasan $(\mathrm{P})$ terdiriatas 3 taraf yaitu $\mathrm{P}_{0}=$ Kontrol (tanpa pemangkasan), $\mathrm{P}_{1}=$ pemangkasan wiwilan, $\mathrm{P}_{2}=$ pemangkasan cabang utama. Hasil penelitian menunjukkan bahwa terdapat interaksi yang sangat nyata pada tinggi tanaman tomat umur 28, 42 HSPT dan diameter buah. Namun, tidak terdapat interaksi yang nyata antara pengujian pupuk Agrobost dengan pemangkasan pada parameter tinggi tanaman umur 14 HSPT, diameter tanaman umur 14, 28, dan 42 HSPT, jumlah bunga, jumlah buah dan berat buah. Kombinasi perlakuan terbaik untuk pertumbuhan dan hasil tanaman tomat dijumpai pada konsentrasi pupuk hayati Agrobost $15 \mathrm{cc} / \mathrm{L}$ air dan pemangkasan cabang utama.
\end{abstract}

Kata kunci: Tomat, Kosentrasi Pupuk Hayati Agrobost, Pemangkasan

\begin{abstract}
Agrobost Biofertilizer and pruning on the right tomato plants and know the interaction between Agrobost Biofertilizer concentration and pruning on the growth and yield of tomato plants. This research was carried out in the Eastern experimental garden, Faculty of Agriculture, Syiah Kuala University, which lasted from November to February 2018. The design used was a Randomized Block Design (RBD) with a $5 \times 3$ factorial pattern with three replications. The factors studied were the concentration of Agrobost Biological Fertilizer (K) consisting of 5 levels, namely Ko $=$ Control (without Agrobost biofertilizer), $\mathrm{K}_{1}=5 \mathrm{cc} / \mathrm{L}$ water, $\mathrm{K}_{2}=10 \mathrm{cc} / \mathrm{L}$ water, $\mathrm{K}_{3}=15 \mathrm{cc} / \mathrm{L}$ water, $\mathrm{K}_{4}=20 \mathrm{cc} / \mathrm{L}$ water. The second factor is pruning $(\mathrm{P})$ consisting of 3 levels, namely $\mathrm{P}_{0}=$ Control (without pruning), $\mathrm{P}_{1}=$ pruning wiwilan, $\mathrm{P}_{2}=$ pruning the main branch. The results there was a very real interaction on the height of tomato plants aged 28, 42 HSPT and fruit diameter. However, there was no interaction between manure and the parameters of plant age 14 HSPT, plant diameters 14, 28, and 42 HSPT, number of flowers, number of fruits and weight of fruit. The best combination of plants for growth and yield of tomato plants was found at the concentration of Agrobost biofertilizers $15 \mathrm{cc} / \mathrm{L}$ water and pruning of the main branches.
\end{abstract}

Keywords: Tomatoes, Agrobost Biofertilizer Concentration, Pruning

\section{PENDAHULUAN}

Tomat (Lycopersicum esculentum Mill.) merupakan salah satu komoditas hortikultura unggulan yang memiliki nilai ekonomi tinggi dalam pemasarannya, hal ini ditandai dengan meningkatnya permintaan akan buah tomat. Produksi tomat di Indonesia pada tahun 2016 mencapai 883.233 atau 0,62 ton/ha, sedangkan di Aceh 25.647 atau 21,59 ton/ha. (Badan Pusat Statistik dan Direktorat Jendral Hortikultura (2016).

Tanaman ini memiliki keunikan karena di golongkan kepada jenis sayuran ataupun buah-buahan. Gizi yang dikandung didalam tomat adalah protein, karbohidrat, lemak, mineral dan vitamin. Manfaat yang terkandung pada buah atau sayuran tomat sangat banyak, bahkan di percaya tomat sebagai pencegah penyakit dan penyembuh penyakit (Iwanudin, 2010). 
Menyadari banyaknya manfaat buah tomat bagi kesehatan dan kebutuhan rumah tangga, maka usaha-usaha kearah peningkatan produksi perlu dilakukan tindakan agronomis yang baik (Purwati dan Khairunnisa, 2007).

Pupuk hayati adalah pupuk organik berupa campuran beberapa jenis mikrorganisme tertentu yang aktif/hidup, diantaranya mikroorganisme pengikat nitrogen, pelarut pospat dan pengurai senyawa organik, yang dapat menyuplai nutrisi yang dibutuhkan oleh tanaman. Pupuk hayati merupakan suatu inokulum mikroba berkemampuan meningkatkan kelarutan hara tanah yang dapat bersifat wide spectrum dan dikemas dalam suatu formula khusus yang bentuk nya dapat berupa suspensi, bubuk, atau butiran. Mikroba yang tepat didalam pupuk hayati dapat menstabil agregat tanah (Suhartatik dan Sismiyati, 2000).

Kandungan pupuk Agrobost yang dibutuhkan dalam proses penyubur tanah secara biologi antara lain: Azospirillium, Azotobacter, mikroba Pelarut P, Lactobacillus, mikroba pendegradasi selulosa, hormon tumbuh indole acetic acid, dan enzim selulase. Mikroba dan enzim tersebut dapat bekerja secara maksimal dan dapat mengubah unsur hara yang tadinya sulit untuk diserap tanaman menjadi unsur hara yang mudah diserap oleh tanaman sehingga penggunaan pupuk menjadi sangat efisien. Jenis-jenis mikroba dan enzim tersebut dapat bekerja secara maksimal. Namun dalam mengaplikasikannya sering terkendala dosis yang belum optimal sehingga perlu diketahui dosis pupuk Agrobost yang tepat agar efisien dan efektif. Agrobost berbahan aktif mikroba indigenous dan tidak mengandung logam berat seperti arsen, timbal, merkuri, kadmium, dan mikroba patogen.

Menurut (Dantri, 2015) pemberian pupuk hayati Agrobost $15 \mathrm{cc} / \mathrm{l}$ air pada tanaman melon berpengaruh terhadap berat buah. Pupuk hayati Agrobost mampu menghemat biaya produksi antara $30 \%$ sampai $40 \%$, dan juga dapat meningkatkan hasil produksi antara $15 \%$ sampai 70\% (Indroputra, 2010). Hasil penelitian (Suryawati et al., 2011) pemberian Agrobost $10 \mathrm{cc} / \mathrm{l}$ air pada tanaman jagung ketan dapat meningkatkan berat tongkol per sampel mencapai $185.00 \mathrm{~g}$ yang berbeda nyata dengan perlakuan tanpa Agrobost. Selanjutnya (Astari, 2014) juga menyatakan bahwa aplikasi Agrobost memberikan pengaruh terhadap diameter batang, panjang akar serta berat basah dan kering akar tanaman tomat (Astari, 2014).

Selain penggunaan pupuk hayati dalam meningkatkan produktivitas tanaman tomat, pemangkasan tanaman juga merupakan usaha yang dilakukan untuk mendapatkan hasil tanaman yang berbuah lebih banyak, pemangkasan bertujuan untuk mengurangi jumlah tunas dan pucuk batang agar pertumbuhan buahnya maksimal. Beberapa pemangkasan pada tomat diantaranya pemangkasan cabang utama, dan pemangkasan wiwilan atau tunas air. Keseluruhan tujuannya adalah agar tanaman dapat memberikan hasil dan kualitas buah yang maksimal (Prajnanta, 1998).

Budidaya tomat terdiri atas beberapa tahapan penting, salah satunya pemangkasan tunas air. Teknik pemangkasan dapat dibedakan menjadi dua yaitu heading back dan thinning out. Heading back dilakukan dengan memotong bagian pucuk cabang sedangkan thinning out membuang cabang lateral (Cahyono, 2008) bagian tanaman tomat yang dapat dipangkas adalah tunas lateral, tunas apical atau bagian pucuk batang tanaman, serta sebagian bunga dan buah.

Pemangkasan dapat menjaga keseimbangan antara pertumbuhan cabang dan buah. Jumlah cabang pada tanaman tomat akan berpengaruh terhadap mutu buah maupun mutu benih. Cabang tanaman yang sedikit memungkinkan mutu buah dan benih dapat meningkat. Asimilat yang terbentuk sepenuhnya dapat disimpan pada buah maupun biji menjadi lebih besar, sehingga mempengaruhi mutu buah maupun benih. Sebaliknya, apabila jumlah cabang pada tanaman tomat banyak, maka asimilat banyak dipergunakan untuk pertumbuhan tunastunas baru, sehingga asimilat yang tersimpan pada buah maupun biji menjadi berkurang dan selanjutnya menyebabkan asimilat yang disimpan pada buah dan biji lebih sedikit. Hal ini 
telah terbukti dalam penelitian (Melulosa, 2002) tanaman tomat dengan satu cabang utama memberikan berat buah sebesar 54,3 g dan ukuran terbaik sebesar 57,4 cm .

Menurut (Sutiastuti, 1993), pemangkasan pada tanaman tomat memberikan pengaruh nyata terhadap diameter buah sebesar $19,75 \mathrm{~cm}$, serta mampu menjaga keseimbangan antara pertumbuhan cabang, jumlah cabang pada tanaman tomat berpengaruh pada mutu buah mau pun mutu benih, pemangkasan dapat mejaga keseimbangan antara pertumbuhan cabang dan buah.

Penelitian ini bertujuan untuk mengetahui konsentrasi pupuk Hayati Agrobost dan pemangkasan pada tanaman tomat yang tapat serta mengetahui interaksi antara konsentrasi pupuk Hayati Agrobost dan pemangkasan terhadap pertumbuhan dan hasil tanaman tomat.

\section{METODELOGI PENELITIAN}

Penelitian ini dilaksanakan dikebun percobaan Sektor Timur Fakultas Pertanian Universitas Syiah Kuala Darussalam Banda Aceh dan Laboratorium Fisiologi Tumbuhan Fakultas Pertanian Universitas Syiah Kuala Banda Aceh. Penelitian ini dilaksanakan pada bulan November 2017 sampai dengan Februari 2018. Alat yang digunakan pada penelitian ini adalah jangka sorong, timbangan analitik, meteran, ajir, tali rafia, wadah/baskom, pipet tetes, ayakan,gembor, hand sprayer, gunting, kertas label, alat tulis, lembar pencatat data dan kamera. Bahan yang digunakan dalam penelitian ini adalah tanah antisol sebanyak $10 \mathrm{~kg}$, pupuk kandang sebanyak $10 \mathrm{~kg}$ (untuk masing-masing per polibag ukuran $40 \mathrm{~cm}$ x $40 \mathrm{~cm}$ dengan perbandingan 2:1), polybag ukuran $15 \mathrm{~cm}$ x $10 \mathrm{~cm}$ untuk pembibitan sebanyak 90 polibag dan polibag $40 \mathrm{~cm}$ x $40 \mathrm{~cm}$ untuk media tanam sebanyak 90 polibag, benih tomat varietas Mutiara pupuk hayati Agrobost, dan pestisida nabati. Penelitian ini menggunakan Rancangan Acak Kelompok (RAK) pola faktorial 5 x 3 yang terdiri dari dua faktor. Faktor pertama konsentrasi pupuk hayati Agrobost $(\mathrm{K})$ terdiri atas 5 taraf yaitu: Ko $=$ Kontrol (tanpa pupuk hayati Agrobost), $\mathrm{K}_{1}=5 \mathrm{cc} / \mathrm{L}$ air, $\mathrm{K}_{2}=10 \mathrm{cc} / \mathrm{L}$ air, $\mathrm{K}_{3}=15 \mathrm{cc} / \mathrm{L}$ air, $\mathrm{K}_{4}=20 \mathrm{cc} / \mathrm{L}$ air, dan faktor kedua pemangkasan $(\mathrm{P})$ terdiri atas 3 taraf yaitu: $\mathrm{P}_{0}=$ Kontrol (tanpa pemangkasan), $\mathrm{P} 1=$ pemangkasan wiwilan, $\mathrm{P} 2=$ pemangkasan cabang utama.

\section{HASIL DAN PEMBAHASAN}

\section{Hasil Penelitian \\ Interaksi antara konsentrasi pupuk hayati Agrobost dan pemangkasan pada tanaman tomat}

\section{Tinggi Tanaman Tomat umur 28 HSPT $(\mathrm{cm})$}

Tabel 1 menunjukkan bahwa perlakuan tanpa pemangkasan $\left(\mathrm{P}_{0}\right)$ pada berbagai konsentrasi pupuk hayati Agrobost didapat tinggi tanaman tomat umur 28 HSPT tertinggi pada konsentrasi pupuk hayati Agrobost $15 \mathrm{cc} / \mathrm{L}$ air $\left(\mathrm{K}_{3}\right)$ berbeda nyata dengan perlakuan lainnya. Pada perlakuan pemangkasan wiwilan $\left(\mathrm{P}_{1}\right)$ dengan berbagai konsentrasi pupuk hayati Agrobost didapat tinggi tanaman tomat umur 28 HSPT tertinggi dijumpai pada konsentrasi pupuk hayati Agrobost $20 \mathrm{cc} / \mathrm{L}$ air $\left(\mathrm{K}_{4}\right)$ yang berbeda tidak nyata dengan perlakuan konsentrasi pupuk hayati Agrobost $15 \mathrm{cc} / \mathrm{L}$ air $\left(\mathrm{K}_{3}\right)$ dan berbeda nyata dengan perlakuan lainnya. Pada pemangkasan cabang utama $\left(\mathrm{P}_{2}\right)$ dengan berbagai konsentrasi pupuk hayati Agrobost didapat tinggi tanaman tomat umur 28 HSPT lebih tinggi dijumpai pada konsentrasi pupuk hayati Agrobost $10 \mathrm{cc} / \mathrm{L}$ air $\left(\mathrm{K}_{2}\right)$ yang berbeda nyata dangan perlakuan konsentrasi 
pupuk hayati Agrobost $0 \mathrm{cc} / \mathrm{L}$ air $\left(\mathrm{K}_{0}\right), 5 \mathrm{cc} / \mathrm{L}$ air $\left(\mathrm{K}_{1}\right)$ dan berbeda tidak nyata pada perlakuan konsentrasi pupuk hayati Agrobost $15 \mathrm{cc} / \mathrm{L}$ air $\left(\mathrm{K}_{3}\right)$ dan $20 \mathrm{cc} / \mathrm{L}$ air $\left(\mathrm{K}_{4}\right)$. Selanjutnya pada perlakuan konsentrasi pupuk hayati Agrobost $0 \mathrm{cc} / \mathrm{L}$ air $\left(\mathrm{K}_{0}\right), 5 \mathrm{cc} / \mathrm{L}$ air $\left(\mathrm{K}_{1}\right), 10 \mathrm{cc} / \mathrm{L}$ air $\left(\mathrm{K}_{2}\right), 15 \mathrm{cc} / \mathrm{L}$ air $\left(\mathrm{K}_{3}\right)$, dan $20 \mathrm{cc} / \mathrm{L}$ air $\left(\mathrm{K}_{4}\right)$ tertinggi dijumpai pada perlakuan pemangkasan cabang utama $\left(\mathrm{P}_{2}\right)$ yang berbeda nyata dengan perlakuan lainnya. Kombinasi perlakuan terhadap tinggi tanaman tomat umur 28 HSPT terbaik dijumpai pada konsentrasi pupuk hayati Agrobost $15 \mathrm{cc} / \mathrm{L}$ air $\left(\mathrm{K}_{3}\right)$ dengan pemangkasan cabang utama $\left(\mathrm{P}_{2}\right)$.

Rata-rata interaksi antara konsentrasi pupuk hayati Agrobost dan Pemangkasan terhadap tinggi tanaman tomat umur 28 HSPT setelah diuji dengan BNJ 0,05 dapat dilihat pada tabel 1 .

Tabel 1. Rata-rata tinggi tanaman tomat umur 28 HSPT akibat konsentrasi pupuk hayati Agrobost dan Pemangkasan

\begin{tabular}{|c|c|c|c|c|c|c|}
\hline \multirow{2}{*}{$\begin{array}{c}\text { Konsentrasi } \\
\text { Pupuk Hayati } \\
\text { Agrobost (cc/L } \\
\text { air) } \\
\end{array}$} & \multicolumn{6}{|c|}{ Pemangkasan } \\
\hline & \multicolumn{2}{|c|}{$\mathrm{P}_{0}$} & \multicolumn{2}{|c|}{$\mathrm{P}_{1}$} & \multicolumn{2}{|c|}{$\mathrm{P}_{2}$} \\
\hline $0\left(\mathrm{~K}_{0}\right)$ & 20,88 & $\mathrm{Aa}$ & 22,97 & $\mathrm{Ab}$ & 25,37 & Ac \\
\hline $5\left(\mathrm{~K}_{1}\right)$ & 23,44 & $\mathrm{Ca}$ & 23,67 & $\mathrm{Aa}$ & 26,37 & $\mathrm{Ab}$ \\
\hline $10\left(\mathrm{~K}_{2}\right)$ & 21,8 & Aba & 24,03 & $\mathrm{Ab}$ & 27,34 & $\mathrm{Bc}$ \\
\hline $15\left(\mathrm{~K}_{3}\right)$ & 25,13 & $\mathrm{Da}$ & 25,55 & $\mathrm{Ba}$ & 27,15 & $\mathrm{Bb}$ \\
\hline $20\left(K_{4}\right)$ & 22,77 & $\mathrm{Bca}$ & 26,13 & $\mathrm{Bb}$ & 27,00 & $\mathrm{Bb}$ \\
\hline
\end{tabular}

Keterangan : Angka yang diikuti oleh huruf kapital pada kolom yang sama dan angka yang diikuti oleh huruf kecil pada baris yang sama berbeda tidak nyata pada taraf $5 \%$ (Uji BNJ 0,05 ).

\section{Tinggi Tanaman Tomat umur 42 HSPT (cm)}

Rata-rata interaksi antara konsentrasi pupuk hayati Agrobost dan Pemangkasan terhadap tinggi tanaman umur 42 HSPT setelah diuji dengan BNJ 0,05 dapat dilihat pada tabel 2.

Tabel 2. Rata-rata tinggi tanaman tomat umur 42 HSPT akibat perlakuan konsentrasi pupuk hayati Agrobost dan Pemangkasan

\begin{tabular}{crlrlll}
\hline $\begin{array}{c}\text { Konsentrasi pupuk } \\
\text { hayati Agrobost } \\
\text { air) }\end{array}$ & \multicolumn{9}{c}{ Pemangkasan } \\
\cline { 2 - 7 } & \multicolumn{1}{c}{$\mathrm{P}_{0}$} & \multicolumn{1}{c}{$\mathrm{P}_{1}$} & \multicolumn{2}{c}{$\mathrm{P}_{2}$} \\
\hline $0\left(\mathrm{~K}_{0}\right)$ & 46,97 & $\mathrm{Aa}$ & 54,83 & $\mathrm{Aa}$ & 64,78 & $\mathrm{Bb}$ \\
$5\left(\mathrm{~K}_{1}\right)$ & 52,8 & $\mathrm{ABa}$ & 54,65 & $\mathrm{Aa}$ & 73,68 & $\mathrm{Cb}$ \\
$10\left(\mathrm{~K}_{2}\right)$ & 49,55 & $\mathrm{ABa}$ & 62,05 & $\mathrm{Ab}$ & 54,64 & $\mathrm{Aab}$ \\
$15\left(\mathrm{~K}_{3}\right)$ & 56,18 & $\mathrm{Ba}$ & 56,37 & $\mathrm{Aa}$ & 56,67 & $\mathrm{ABa}$ \\
$20\left(\mathrm{~K}_{4}\right)$ & 53,03 & $\mathrm{ABa}$ & 71,47 & $\mathrm{Bb}$ & 59,33 & $\mathrm{ABa}$ \\
\hline
\end{tabular}

BNJ 8,22

Keterangan :Angka yang diikuti oleh huruf kapital pada kolom yang sama dan angka yang diikuti oleh huruf kecil pada baris yang sama berbeda tidak nyata pada taraf $5 \%$ ( $\mathrm{Uji} \mathrm{BNJ}_{0,05}$ ).

Tabel 2 menunjukkan bahwa perlakuan tanpa pemangkasan $\left(\mathrm{P}_{0}\right)$ pada berbagai konsentrasi pupuk hayati Agrobost didapat tinggi tanaman tomat umur 42 yang terbaik dijumpai pada konsentrasi pupuk hayati Agrobost $15 \mathrm{cc} / \mathrm{L}$ air $\left(\mathrm{K}_{3}\right)$, berbeda nyata dengan konsentrasi pupuk hayati Agrobost $0 \mathrm{cc} / \mathrm{L}$ air $\left(\mathrm{K}_{0}\right)$, dan berbeda tidak nyata dengan 
konsentrasi pupuk hayati Agrobost lainnya. Pada perlakuan pemangkasan wiwilan $\left(\mathrm{P}_{1}\right)$ dengan berbagai konsentrasi pupuk hayati Agrobost didapat tinggi tanaman tomat umur 42 tertinggi dijumpai pada perlakuan konsentrasi pupuk hayati Agrobost $20 \mathrm{cc} / \mathrm{L}$ air $\left(\mathrm{K}_{4}\right)$, berbeda nyata dengan konsentrasi pupuk hayati Agrobost lainnya. Pada Pemangkasan cabang utama $\left(\mathrm{P}_{2}\right)$ dengan berbagai konsentrasi pupuk hayati Agrobost didapat tinggi tanaman tomat umur 42 yang tertinggi dijumpai pada perlakuan konsentrasi pupuk hayati Agrobost $5 \mathrm{cc} / \mathrm{L}$ air $\left(\mathrm{K}_{1}\right)$, berbeda nyata dengan perlakuan lainnya. Selanjutnya pada perlakuan konsentrasi pupuk hayati Agrobost $0 \mathrm{cc} / \mathrm{L}$ air $\left(\mathrm{K}_{0}\right)$ dan $5 \mathrm{cc} / \mathrm{L}$ air $\left(\mathrm{K}_{1}\right)$ terbaik dijumpai pada perlakuan pemangkasan cabang utama $\left(\mathrm{P}_{2}\right)$, berbeda nyata dengan pemangkasan lainnya. Pada perlakuan konsentrasi pupuk hayati Agrobost $10 \mathrm{cc} / \mathrm{L}$ air $\left(\mathrm{K}_{2}\right)$ yang terbaik dijumpai pada perlakuan pemangkasan wiwilan $\left(\mathrm{P}_{1}\right)$, berbeda nyata dengan tanpa pemangkasan $\left(\mathrm{P}_{0}\right)$ dan berbeda tidak nyata dengan pemangkasan cabang utama $\left(\mathrm{P}_{2}\right)$. Pada perlakuan konsentrasi pupuk hayati Agrobost $15 \mathrm{cc} / \mathrm{L}$ air $\left(\mathrm{K}_{3}\right)$ yang baik dijumpai pada perlakuan pemangkasan cabang utama $\left(\mathrm{P}_{2}\right)$, berbeda tidak nyata dengan pemangkasan lainnya. Pada perlakuan konsentrasi pupuk hayati Agrobost $20 \mathrm{cc} / \mathrm{L}$ air $\left(\mathrm{K}_{4}\right)$ yang terbaik dijumpai pada perlakuan pemangkasan wiwilan $\left(\mathrm{P}_{1}\right)$, berbeda nyata dengan pemangkasan lainnya. Kombinasi perlakuan terhadap tinggi tanaman umur 42 HSPT terbaik dijumpai pada konsentrasi pupuk hayati Agrobost $5 \mathrm{cc} / \mathrm{L}$ air $\left(\mathrm{K}_{1}\right)$ dengan pemangkasan cabang utama $\left(\mathrm{P}_{2}\right)$.

\section{Diameter Buah Tanaman Tomat (mm)}

Rata-rata interaksi antara konsentrasi pupuk hayati Agrobostdan Pemangkasan terhadap diameter buah setelah diuji dengan BNJ 0,05 dapat dilihat pada tabel 3.

Tabel 3. Rata-rata diameter buah tomat akibat perlakuan konsentrasi pupuk hayati Agrobost dan Pemangkasan

\begin{tabular}{cccccccc}
\hline $\begin{array}{c}\text { Pupuk hayati } \\
\text { Agrobost cc/L } \\
\text { air }\end{array}$ & $\mathrm{P}_{0}$ & \multicolumn{9}{c}{ Pemangkasan } \\
\cline { 2 - 8 } & 6,10 & $\mathrm{Aa}$ & 5,82 & $\mathrm{Aa}$ & $\mathrm{P}_{2}$ & \\
\hline $0\left(\mathrm{~K}_{0}\right)$ & 6,02 & $\mathrm{Aa}$ & 6,54 & $\mathrm{Aba}$ & 5,90 & $\mathrm{Aa}$ \\
$5\left(\mathrm{~K}_{1}\right)$ & 8,05 & $\mathrm{Ca}$ & 7,73 & $\mathrm{Ca}$ & 6,50 & $\mathrm{Aa}$ \\
$10\left(\mathrm{~K}_{2}\right)$ & 7,69 & $\mathrm{Bab}$ & 7,16 & $\mathrm{Ba}$ & 7,75 & $\mathrm{Ba}$ \\
$15\left(\mathrm{~K}_{3}\right)$ & 6,30 & $\mathrm{Aa}$ & 5,58 & $\mathrm{Aa}$ & 8,78 & $\mathrm{Cb}$ \\
$20\left(\mathrm{~K}_{4}\right)$ & & & 6,08 & $\mathrm{Aa}$ \\
\hline
\end{tabular}

$\mathrm{BNJ}$

14,38

Keterangan : Angka yang diikuti oleh huruf kapital pada kolom yang sama dan angka yang diikuti oleh huruf kecil pada baris yang sama berbeda tidak nyata pda taraf $5 \%\left(\mathrm{Uji} \mathrm{BNJ}_{0,05}\right)$.

Tabel 3 menunjukkan bahwa perlakuan tanpa pemangkasan $\left(\mathrm{P}_{0}\right)$ dan pemangkasan wiwilan $\left(\mathrm{P}_{1}\right)$ pada berbagai konsentrasi pupuk hayati Agrobost didapat diameter buah tanaman tomat tertinggi pada konsentrasi pupuk hayati Agrobost $10 \mathrm{cc} / \mathrm{L}$ air $\left(\mathrm{K}_{2}\right)$ berbeda tidak nyata dengan konsentrasi pupuk hayati Agrobost lainnya. Pada perlakuan pemangkasan cabang utama $\left(\mathrm{P}_{2}\right)$ dengan berbagai konsentrasi pupuk hayati Agrobost didapat diameter buah tanaman tomat yang tertinggi dijumpai pada perlakuan konsentrasi pupuk Agrobost $15 \mathrm{cc} / \mathrm{L}$ air $\left(\mathrm{K}_{3}\right)$ berbeda nyata dengan konsentrasi pupuk hayati Agrobost lainnya. Selanjutnya pada perlakuan konsentrasi pupuk hayati Agrobost $0 \mathrm{cc} / \mathrm{L}$ air $\left(\mathrm{K}_{0}\right)$ yang lebih baik dijumpai pada perlakuan tanpa pemangkasan $\left(\mathrm{P}_{0}\right)$, yang berbeda tidak nyata dengan pemangkasan lainnya. Pada perlakuan konsentrasi pupuk Agrobost $5 \mathrm{cc} / \mathrm{L}$ air $\left(\mathrm{K}_{3}\right)$ yang lebih baik dijumpai pada perlakuan pemangkasan wiwilan $\left(\mathrm{P}_{1}\right)$ berbeda tidak nyata dengan tanpa pemangkasan lainnya. Pada perlakuan konsentrasi pupuk hayati Agrobost $10 \mathrm{cc} / \mathrm{L}$ air $\left(\mathrm{K}_{2}\right)$ yang lebih baik dijumpai 
pada perlakuan tanpa pemangkasan $\left(\mathrm{P}_{0}\right)$ berbeda tidak nyata dengan pemangkasan lainnya. Pada perlakuan konsentrasi pupuk hayati Agrobost $15 \mathrm{cc} / \mathrm{L}$ air $\left(\mathrm{K}_{3}\right)$ yang lebih baik dijumpai pada perlakuan pemangkasan cabang utama $\left(\mathrm{P}_{2}\right)$ berbeda tidak nyata dengan tanpa pemangkasan $\left(\mathrm{P}_{0}\right)$ namun berbeda nyata dengan pemangkasan wiwilan $\left(\mathrm{P}_{1}\right)$. Pada perlakuan konsentrasi pupuk hayati Agrobost $20 \mathrm{cc} / \mathrm{L}$ air $\left(\mathrm{K}_{4}\right)$ yang lebih baik dijumpai pada perlakuan tanpa pemangkasan $\left(\mathrm{P}_{0}\right)$ berbeda tidak nyata dengan pemangkasan lainnya.Kombinasi perlakuan terhadap diameter buah tomat terbaik dijumpai pada konsentrasi pupuk hayati Agrobost $15 \mathrm{cc} / \mathrm{L}$ air $\left(\mathrm{K}_{3}\right)$ dengan pemangkasan cabang utama $\left(\mathrm{P}_{2}\right)$.

\section{Pembahasan}

\section{Pengaruh interaksi antara konsentrasi pupuk Agrobost dan pemangkasan terhadap pertumbuhan dan hasil tanaman tomat}

Berdasarkan hasil analisis yang telah diuraikan menunjukkan bahwa konsentrasi pupuk hayati Agrobost dan pemangkasan menunjukan interaksi yang sangat nyata terhadap tinggi tanaman umur 28,42 HSPT, diameter buah dan terdapat interaksi yang tidak nyata terhadap diameter batang, jumlah bunga, jumlah buah dan berat buah tanaman tomat.

Dari berbagai konsentrasi pupuk hayati Agrobost dan pemangkasan yang telah dicobakan, pertumbuhan dan hasil tanaman tomat yang terbaik dijumpai pada kombinasi perlakuan antara konsentrasi pupuk hayati Agrobost $15 \mathrm{cc} / \mathrm{L}$ air $\left(\mathrm{K}_{3}\right)$ dan perlakuan pemangkasan cabang utama $\left(\mathrm{P}_{2}\right)$.

Menurut (Rizky, 2015), menyatakan bahwa pemberian pupuk hayati Agrobost $15 \mathrm{cc} / \mathrm{L}$ air mempengaruhi pertumbuhan tanaman cabai. jumlah buah cabai, hal ini menunjukkan bahwa pemberian pupuk hayati mampu meningkatkan pertumbuhan tanaman cabai oleh aktivitas berbagai mikroorganisme seperti jamur dan bakteri. Hal ini sesuai dengan pendapat Gunalan (1996), yang menyatakan bahwa mikroorganisme tanah yang bermanfaat yaitu sejumlah jamur dan bakteri kerena kemampuannya melaksanakan fungsi metabolisme sangat menguntungkan bagi pertumbuhan tanaman.

Pupuk hayati Agrobost dengan formulasi cair diaplikasikan dengan cara disiramkan ketanah perakaran. Adapun unsur hara dalam pupuk Agrobost seperti kalium dengan konsentrasi 1773 ppm merupakan bahan aktif dari sejumlah besar enzim yang penting untuk proses fotosintesis dan respirasi, kalium mengaktifkan juga enzim yang membentuk pati dan proteinPengaruh yang nyata pada faktor produksi tanaman tomat (tinggi tanaman, berat buah, dan diameter buah) (Hamzah et al., 2011).

Lebih lanjut (Sutedjo 2001) menjelaskan, bahwa bila salah satu faktor lebih kuat pengaruhnya dari faktor lain sehingga faktor lain tersebut tertutupi dan masing-masing faktor mempunyai sifat yang jauh berbeda pengaruh dan sifat kerjanya, maka tidak akan menghasilkan hubungan nyata dalam mempengaruhi pertumbuhan tanaman.

Pupuk hayati Agrobost merupakan inokulan berbahan aktif organisme hidup yang berfungsi untuk menambat hara tertentu dalam tanah bagi tanaman. Pupuk berbasis mikroba digolongkanke dalam pupuk hayati karena merupakan suatu inokulan berbahan aktiforganisme hidup yang berfungsi untuk menambat hara tertentu dalam tanah bagitanaman, pupuk hayati merupakan mikroba yang diberikan kedalam tanah yangberfungsi meningkatkan pengambilan hara oleh tanaman dari dalam tanah atau udara (Hamastuti, 2012)

Hasil penelitian tidak nyata diduga karena kedua faktor yang digunakan pada penelitian belum saling mendukung seperti iklim, konsentrasi pupuk yang terlalu tinggi dan belum sesuai dengan kriteria pemangkasan sehingga interaksi yang ditimbulkan kedua faktor tersebut tidak berbeda nyata (Hamzah et al.,2011). 


\section{SIMPULAN DAN SARAN}

Dari hasil penelitian yang telah dilakukan, dapat diambil kesimpulan bahwa pertumbuhan dan hasil terbaik dijumpai pada kombinasi perlakuan konsentrasi pupuk hayati Agrobost $15 \mathrm{cc} / \mathrm{L}$ air dengan perlakuan pemangkasan Cabang Utama. Perlu dilakukan penelitian lanjutan dengan konsentrasi pupuk hayati Agrobost dan pemangkasan yang terbaik pada tanaman lain nya.

\section{DAFTAR PUSTAKA \\ (format yang dipergunakan APA \& Harvard)}

Astari. 2014. Dasar-dasar Hortikultura: Bumi Aksara, Jakarta.

Badan Pusat Statistik dan Direktorat Jenderal Holtikultura, Departemen Pertanian 2016. Produktivitas sayuran di Indonesia, Jakarta.

Cahyono, B. 2008. Tomat Budidaya dan Analisis Usaha Tani. Kanisius, Yogyakarta

Dantri. 2015. Laporan Akhir Profil Komoditas Tomat. Pusat Penelitian dan Pengembangan Hortikultura, Badan Penelitian dan Pengembangan Pertanian.

Gunalan. 1996. Hasil Tanaman Jagung (Zea mays) Pada Berbagai Pupuk Hayati dan Pemangkasan. Laporan Penelitian. Universitas Jambi, Jambi.

Hamzah, S., Sri, U dan Cholik, A. 2011. Pengaruh pupuk agrobost dan humagold terhadap pertumbuhan dan produksi jagung ketan (Zea mays ceratina). Agrium. 17(1) : 50-59.

Iwanudin. 2010. Khasiat dan Manfaat Tomat. http://blog..com// (Diakses 19 febuari 2017).

Melulosa. 2002. Pengaruh Jumlah Cubang Utama dan Takaran Pupuk Kandang Sapi terhadap Pertumbuhan, Hasil dan Kualitas Tomat, Yogyakarta.

Prajnanta, F. 1998. Agribisnis Cabai Hibrida. Penebar Swadaya, Jakarta.

Purwati dan Khairunisa. 2007 klasifikasi-danmorfologitomat,[online](https://bukuteori.com, [5 september 2018].

Rizky. 2015. Pemupukan dan Pemangkasan Terhadap Tanaman Cabai (capsicum anum). Universitas Sumatra Utara.

Sutiastuti. 1993. Pengaruh Dosis Pupuk N dan Pemangkasan Terhadap Pertumbuhan dan Hasil Tomat (Lycopersicum esculentum Mill). Skripsi Fakultas Pertanian Universitas Muhamadiyah Yogyakarta.

Suhartatik E. dan Sismiyati, R. 2000. Pemanfaatan pupuk organik dan agen hayati pada padi sawah.

Suryawati, H. 2011. Pengaruh Pupuk Agrobost dan Humagold Terhadap Pertumbuhan dan Produksi Jagung Ketan (Zea mays).Skripsi Fakultas Pertanian Universitas Sumatra Utara. 